\title{
PENERAPAN KEBIJAKAN DALAM PENDIDIKAN ISLAM (Studi Bentuk-Bentuk Analisis Kebijakan)
}

\author{
Mohammad Ahyan Yusuf Sya'bani \\ Universitas Muhammadiyah Gresik \\ E-mail: ahyanyusuf@umg.ac.id
}

\begin{abstract}
Abstrak: Suatu kebijakan akan terlaksana manakala didukung oleh berbagai lapisan dan bidang serta sumber daya manusia yang memadai. Namun secara realitas kebijakan terkadang tidak berjalan dengan sempurna dan optimal dikarenakan terkendala dengan peran sumber daya manusia yang tidak menjalankan fungsi kebijakan dan juga sebab eksternal yang melatarbelakangi. Hasil penelitian menunjukkan bahwa beragam bentuk analisis kebijakan pendidikan Islam berupa (1) analisis kebijakan prospektif yang berupa produksi dan transformasi informasi sebelum aksi kebijakan dimulai dan diimplementasikan cenderung memiliki ciri cara beroperasinya para ekonom, analis sistem, dan peneliti operasi; (2) analisis retrospeksi berupa analisis berorientasi disiplin, masalah, dan aplikasi; (3) analisis kebijakan yang terintegrasi merupakan bentuk analisis yang mengombinasikan gaya operasi para praktisi yang menaruh perhatian pada penciptaan dan transformasi informasi sebelum dan sesudah tindakan kebijakan diambil.
\end{abstract}

Kata Kunci: kebijakan pendidikan, pendidikan islam 


\section{PENDAHULUAN}

etiap lahirnya produk kebijakan maka tentu sangat dipengaruhi langkah kebijakan apa yang telah diambil. Oleh karena itu jika ditarik pada dunia pendidikan maka kebijakan pendidikanlah yang banyak mempengaruhi adanya segala bentuk dari kegiatan pendidikan itu sendiri. Dalam hal ini dapat dinyatakan dunia pendidikan tidak akan pernah lepas dari suatu kebijakan. Kebijakan mengenai pendidikan tentunya juga mengandung beberapa aspek di dalamnya yang bersifat konstruktif agar pendidikan dapat berjalan sesuai dengan tujuan diselenggarakannya pendidikan tersebut.

Kebijakan yang terdapat dalam dunia pendidikan mengharuskan para peneliti, praktisi pendidikan dan masyarakat umum tidak hanya bisa menunggu hasil dari adanya kebijakan pendidikan tersebut namun perlu untuk mengetahui adanya suatu analisis kebijakan di dalamnya agar proses berjalannya suatu kebijakan dapat terkontrol dengan baik dan sesuai dengan arah tujuan yang hendak dicapai bersama.

Analisis kebijakan merupakan aktivitas menciptakan pengetahuan tentang dan dalam proses pembuatan kebijakan. Dalam menciptakan pengetahuan tentang proses pembuatan kebijakan analis kebijakan meneliti sebab, akibat, dan kinerja kebijakan dan program publik.
Pengetahuan tersebut betapa pun tetap tidak lengkap kecuali jika hal tersebut disediakan kepada pengambil kebijakan dan publik terhadap siapa para analis berkewajiban melayaninya. Hanya jika pengetahuan tentang kebijakan dikaitkan dengan pengetahuan dalam proses kebijakan bersama dengan warga negara yang memiliki peranan dalam keputusan-keputusan publik, dapat menggunakan hasil-hasil analisis kebijakan untuk memperbaiki proses pembuatan kebijakan dan kinerjanya. Karena efektivitas pembuatan kebijakan tergantung pada akses terhadap stok pengetahuan yang tersedia, komunikasi dan penggunaan analisis kebijakan menjadi penting sekali dalam praktik dan teori pembuatan kebijakan publik.

Berdasarkan berbagai uraian dari latar belakang di atas menjadikan adanya suatu penjelasan yang dirasa perlu untuk mengungkapkan dengan jelas maksud dari analisis kebijakan dengan sebenarnya. Oleh karena itu perlu diuraikan beberapa rumusan masalah yang akan dibahas dalam penelitian ini yaitu pengertian dari analisis kebijakan dan bentuk-bentuk analisis kebijakan.

\section{HASIL DAN PEMBAHASAN}

\section{Pengertian Analisis Kebijakan}

Mengenai definisi analisis kebijakan E.S. Quade yang pernah menjabat sebagai 
Kepala Departemen Matematika di perusahaan Rand mencoba memberikan suatu rumusan tentang makna dan konsep analisis kebijakan dan berusaha menyajikan dasar kebijakan untuk mendefinisikan analisis kebijakan. Menurut pendapatnya analisis kebijakan ialah:

Suatu bentuk analisis yang menghasilkan dan menyajikan informasi sedemikian rupa sehingga dapat memberi landasan dari para pembuat kebijakan dalam membuat keputusan. Dalam analisis kebijakan, kata analisis digunakan dalam pengertian yang paling umum; termasuk penggunaan intuisi dan pengungkapan pendapat dan mencakup tidak hanya pengujian kebijakan dengan memilah-milahnya ke dalam sejumlah komponen-komponen tetapi juga perancangan dan sintesis alternatif-alternatif baru. Kegiatan-kegiatan yang tercakup dapat direntangkan mulai penelitian untuk menjelaskan atau memberikan pandanganpandangan terhadap isu-isu atau masalahmasalah yang terantisipasi sampai mengevaluasi suatu program yang lengkap. Beberapa analisis kebijakan bersifat informal, meliputi tidak lebih dari proses berpikir yang keras dan cermat, sementara lainnya memerlukan pengumpulan data yang ekstensif dan penghitungan yang teliti

\footnotetext{
${ }^{1}$ E.S. Quade, Analysis for Public Decisions, (New York: American Elsevier Publishing Co., 1975), hlm. 4.
}

dengan menggunakan proses matematis yang canggih. ${ }^{1}$

Pengertian dasar dapat diartikan sebagai pengungkapan arti analisis kebijakan yang berlaku umum dan dapat diterapkan dalam berbagai konteks. Analisis kebijakan merupakan suatu prosedur berpikir yang sudah lama dikenal dan dilakukan dalam sejarah manusia, paling tidak sejak manusia mampu melahirkan dan memelihara pengetahuan dalam kaitannya dengan tindakan.

Menurut William Dunn yang dikutip oleh Ace Suryadi dan H.A.R. Tilaar dalam bukunya Analisis Kebijakan Pendidikan Suatu Pengantar bahwasanya analisis kebijakan dapat diartikan secara umum yakni analisis kebijakan ialah suatu prosedur untuk menghasilkan informasi mengenai masalah-masalah kemasyarakatan berikut tindakan pemecahannya. ${ }^{2}$ Sedangkan di pihak lain Ace Suryadi dan H.A.R. Tilaar juga mengambil pendapat dari Patton tentang definisi analisis kebijakan yang menjelaskan bahwa analisis kebijakan ialah suatu rangkaian proses dalam menghasilkan kebijakan. $^{3}$

Adapun pendapat lain yang diuraikan oleh Duncan MacRae yang juga dikutip oleh

\footnotetext{
${ }^{2}$ Ace Suryadi dan H.A.R. Tilaar, Analisis Kebijakan Pendidikan Suatu Pengantar, (Bandung: Remaja Rosdakarya, 1993), hlm. 40.

${ }^{3}$ Ibid., hlm. 40.
} 
Ace Suryadi dan H.A.R. Tilaar tentang definisi analisis kebijakan menjelaskan bahwa analisis kebijakan sebagai suatu disiplin ilmu sosial terapan yang menggunakan argumentasi rasional dengan menggunakan fakta-fakta untuk menjelaskan, menilai, dan membuahkan pemikiran dalam rangka upaya memecahkan masalah publik. ${ }^{4}$

Hal senada juga diungkapkan oleh Ace Suryadi dan H.A.R. Tilaar di dalam buku Analisis Kebijakan Pendidikan Suatu Pengantar yang mengutip pendapat Stokey dan Zekhauser yang berusaha memberikan pengertian tentang analisis kebijakan. Mereka mengartikan analisis kebijakan adalah sebagai suatu proses rasional dengan menggunakan metode dan teknik yang rasional pula..$^{5}$

Demikian juga menurut pendapat Riant Nugroho yang mengutip pendapat Carl W. Patton dan David S. Savicky dengan kritis menjelaskan bahwa analisis kebijakan adalah tindakan yang diperlukan untuk dibuatnya sebuah kebijakan, baik kebijakan yang baru sama sekali atau kebijakan yang baru sebagai konsekuensi dari kebijakan yang ada. ${ }^{6}$

Analisis kebijakan bekerja dalam sebuah lingkungan yang serba terbatas: waktu, informasi, bahkan pengetahuan.
Analisa kebijakan adalah profesi yang sangat diperlukan oleh setiap pemimpin puncak di berbagai lembaga administrasi publik, pada setiap jenjang. Di negaranegara maju, para kepala negara biasanya didampingi oleh analis-analis kebijakan yang excellent yang memungkinkan mereka mengambil keputusan atau kebijakan yang cepat namun efektif dalam pelaksanaannya.

Analisis kebijakan, dalam pengertiannya yang luas, melibatkan hasil pengetahuan tentang dan di dalam proses kebijakan. Secara historis, tujuan analisis kebijakan adalah menyediakan informasi bagi pembuat kebijakan untuk dijadikan bahan pertimbangan yang nalar guna menemukan pemecahan masalah kebijakan. Analisis kebijakan mengambil dari berbagai disiplin yang tujuannya bersifat deskriptif, evaluatif, dan normatif. Analisis kebijakan diharapkan untuk menghasilkan dan mentransformasikan informasi tentang nilai-nilai, faktafakta, dan tindakan-tindakan. Ketiga macam tipe informasi itu dihubungkan dengan tiga pendekatan analisis kebijakan, yaitu empiris, valuatif, dan normatif. Komunikasi dan penggunaan pengetahuan yang relevan dengan kebijakan adalah sentral dalam praktik dan teori analisis kebijakan. Metodologi analisis kebijakan adalah sistem

\footnotetext{
${ }^{6}$ Riant Nugroho D., Kebijakan Publik (Formulasi, Implementasi, dan Evaluasi), (Jakarta: Gramedia, 2004), hlm. 84.
} 
standar, aturan, dan prosedur untuk menciptakan, secara kritis menilai, dan mengkomunikasikan pengetahuan yang relevan dengan kebijakan. Metodologi analisis kebijakan mempunyai beberapa karakteristik utama : perhatian yang tinggi pada perumusan dan pemecahan masalah, komitmen kepada pengkajian baik yang sifatnya deskriptif maupun kritik nilai, dan keinginan untuk meningkatkan efisiensi pilihan di antara sejumlah alternatif lain. ${ }^{7}$

Lima tipe informasi yang dihasilkan oleh analisis kebijakan adalah: masalah kebijakan, masa depan kebijakan, aksi kebijakan, hasil kebijakan, dan kinerja kebijakan. Kelima tipe informasi tersebut diperoleh melalui lima prosedur analisis kebijakan: perumusan masalah, peramalan, rekomendasi, pemantauan, dan evaluasi.

Rekomendasi merupakan proses rasional di mana para analis memproduksi informasi dan argumen-argumen yang beralasan tentang solusi-solusi yang potensial dari masalah publik. Prosedurprosedur yang paling umum untuk memecahkan masalah-masalah kemanusiaan (deskripsi, prediksi, evaluasi, preskripsi) dapat dibandingkan dan dipertimbangkan menurut waktu kapan prosedurprosedur tersebut digunakan (sebelum atau

7 Rahmansyah Ritonga, Analisis Kebijakan, http://sumut.kemenag.go.id/file/file/Analisis/yxgf13 sesudah tindakan) dan jenis pertanyaan yang sesuai (empiris, valuatif, normatif). Setiap argumen kebijakan mempunyai enam elemen: informasi yang relevan dengan kebijakan, klaim kebijakan, pembenaran, dukungan, bantahan, dan penguat. Analisis kebijakan umunya bersifat kognitif, sedangkan pembuat kebijakan bersifat politis. Sistem kebijakan bersifat dialektis, merupakan kreasi subjektif dari pelaku kebijakan, merupakan realitas objektif, dan para pelaku kebijakan merupakan produk dari sistem kebijakan. ${ }^{8}$

\section{Bentuk-Bentuk Analisis Kebijakan}

Hubungan antara komponen-komponen informasi kebijakan dan metode-metode analisis kebijakan memberi landasan untuk membedakan tiga bentuk utama analisis kebijakan: analisis prospektif, retrospektif, dan terintegrasi.

\section{Analisis Kebijakan Prospektif}

Analisis kebijakan prospektif yang berupa produksi dan transformasi informasi sebelum aksi kebijakan dimulai dan diimplementasikan cenderung memiliki ciri cara beroperasinya para ekonom, analis sistem, dan peneliti operasi. Analisis kebijakan prospektif mungkin paling baik

33599466.pdf, diakses pada tanggal 10 Juli 2019 pukul 11.53 WIB.

${ }^{8} \mathrm{Ibid}$. 
dicontohkan dari deskripsi analisis kebijakan yang diberikan oleh Walter Williams, mantan Kepala Divisi Penelitian dan Perencanaan pada kantor Kesempatan Ekonomi (the Office of Economic Opportunity).

Analisis kebijakan, menurut Walter Williams yang dikutip oleh William Dunn menyatakan bahwa analisis kebijakan ialah suatu alat untuk mensintesakan informasi untuk dipakai dalam merumuskan alternatif dan preferensi kebijakan yang dinyatakan secara komparatif, diramalkan dalam bahasa kuantitatif dan kualitatif sebagai landasan atau penuntun dalam pengambilan keputusan kebijakan; secara konseptual tidak termasuk mengumpulkan informasi. Sebaliknya penelitian kebijakan berkenaan dengan semua studi yang menggunakan metodologi ilmiah untuk menerangkan fenomena dan/atau menentukan hubungan di antara mereka. ${ }^{9}$

Analisis prospektif acapkali menimbulkan jurang pemisah yang besar antara pemecahan masalah yang diunggulkan dan upaya-upaya pemerintah untuk memecahkannya. Misalnya pakar ilmu politik Graham Allison memperkirakan bahwa mungkin tidak lebih dari 10 persen dari kerja yang diperlukan untuk mencapai seperangkat

\footnotetext{
${ }^{9}$ William Dunn, Pengantar Analisis Kebijakan Publik, terj. Samodra Wibawa, dkk, (Yogyakarta: Gadjah Mada University Press, 2003), hlm. 118.
}

hasil kebijakan yang dikehendaki diperoleh sebelum aksi kebijakan dimulai:

Itu bukan berarti bahwa kita mempunyai terlalu banyak solusi analitis yang baik terhadap masalah. Melainkan, kita mempunyai lebih banyak solusi yang baik ketimbang mempunyai aksi yang tepat. Perspektif ini menyarankan bahwa pertanyaan pokok dari analisis kebijakan berbeda dengan macam-macam pertanyaan yang secara tradisional ditanyakan. ${ }^{10}$

\section{Analisis Kebijakan Retrospektif}

Analisis kebijakan retrospektif dalam banyak hlm sesuai dengan deskripsi penelitian kebijakan yang dikemukakan sebelumnya. Analisis retrospektif, yang dijelaskan sebagai penciptaan dan transformasi informasi sesudah aksi kebijakan dilakukan, mancakup berbagai tipe kegiatan yang dikembangkan oleh tiga kelompok analisis:

a. Analisis yang berorientasi pada disiplin (Discipline-oriented analysis)

Kelompok ini sebagian besar terdiri dari para ilmuwan politik dan sosiologi, terutama berusaha untuk mengembangkan dan menguji teori yang didasarkan pada teori dan menerangkan

\footnotetext{
10 Graham T. Allison, Essence of Decision: Explaining the Cuban Missile Crisis, (Boston: Litlle, Brown and Company, 1971), hlm. 267-268.
} 
sebab-sebab dan konsekuensikonsekuensi kebijakan. Kelompok ini jarang berusaha untuk mengidentifikasikan tujuan-tujuan dan sasaran spesifik dari para pembuat kebijakan dan tidak melakukan usaha apa pun untuk membedakan "variabel-variabel kebijakan yang merupakan hal yang dapat diubah melalui manipulasi kebijakan, dan variabel situasional yang tidak dapat dimanipulasi. ${ }^{11}$

Adapun contohnya yaitu analisis mengenai pengaruh kompetisi partai terhadap tingkat pengeluaran pemerintah tidak menghasilkan informasi tentang tujuan jangka pendek dan tujuan jangka panjang yang spesifik dari para pembuat kebijakan; kompetisi partai juga bukan merupakan variabel yang dapat dimanipulasi yang dapat digunakan oleh para pembuat kebijakan untuk menghasilkan perubahan dalam pengeluaran pemerintah.

b. Analisis yang berorientasi pada masalah (Problem-oriented analysis)

Kelompok ini sebagian besar juga terdiri dari para ilmuwan ilmu politik dan sosiologi, dan juga berusaha untuk menerangkan sebab-sebab dan konse- kuensi dari kebijakan. Meskipun begitu, para analis yang berorientasi pada masalah ini, kurang "menaruh" perhatian pada pengembangan dan pengujian teori-teori yang dianggap penting di dalam disiplin ilmu sosial, tetapi lebih menaruh perhatian pada identifikasi variabel-variabel yang dapat dimanipulasi oleh para pembuat kebijakan untuk mengatasi masalah. ${ }^{12}$

Walaupun begitu, analis yang berorientasi pada masalah jarang menyajikan informasi mengenai tujuan dan sasaran kebijakan yang spesifik dari para pembuat kebijakan, terutama karena masalah-masalah praktis yang dianalisis biasanya bersifat umum. Sebagai contoh, analisis pengaruh investasi publik dalam bidang pendidikan terhadap prestasi muridmurid di Amerika Serikat memberikan informasi tentang variabel yang dapat dimanipulasi (investasi publik) tetapi tidak memberikan informasi tentang sasaran yang khusus dari para pembuat kebijakan dan pelaku kebijakan lainnya yang mempengaruhi dan dipengaruhi oleh kebijakan pendidikan.

(Beverly Hill and London: Sage Publications, 1975), hlm. 25 .

12 William Dunn, Pengantar Analisis..., hlm. 120. 
c. Analisis yang berorientasi pada aplikasi (Applications-oriented analysis).

Kelompok analis yang ketiga ini mencakup ilmuwan politik dan sosiologi, tetapi juga orang-orang yang datang dari bidang studi profesional pekerjaan sosial (social work) dan administrasi publik dan bidang studi yang sejenis seperti penelitian evaluasi. Kelompok ini juga berusaha untuk menerangkan sebab dan konsekuensi kebijakan-kebijakan dan program publik, tetapi tidak menaruh perhatian terhadap pengembangan dan pengujian teori-teori dasar. Lebih jauh, kelompok ini tidak hanya menaruh perhatian pada variabel-variabel kebijakan, tetapi juga melakukan identifikasi tujuan dan sasaran kebijakan dari para pembuat kebijakan dan pelaku kebijakan. Informasi mengenai tujuan-tujuan dan sasaran kebijakan memberi landasan bagi pemantauan dan evaluasi hasil kebijakan yang spesifik, yang dapat digunakan oleh para praktisi untuk merumuskan masalah-masalah kebijakan, mengembangkan alternatif-alternatif kebijakan baru, dan merekomendasikan arah tindakan untuk memecahkan masalah. ${ }^{13}$
Sebagai contoh, para analis yang berorientasi pada aplikasi ini dapat membuat perhitungan mengenai faktorfaktor yang mempengaruhi keberhasilan dan kegagalan program pendidikan anak-anak prasekolah, walaupun analisis mereka berakhir dengan perumusan masalah-masalah dan pengembangan suatu sintesis pemecahan masalah-masalah kebijakan.

Gaya pengoperasian ketiga kelompok analis kebijakan retrospektif tersebut memiliki kelebihan dan kelemahannya sendirisendiri. Analis kebijakan yang berorientasi pada disiplin jarang menghasilkan informasi yang secara langsung bermanfaat untuk merumuskan pemecahan atas masalahmasalah kebijakan, terutama karena variabel-variabel yang paling relevan bagi pengujian teori-teori ilmiah umum juga jarang dapat digunakan oleh pembuat kebijakan untuk melakukan manipulasi kebijakan.

Bahkan ketika para analis yang berorientasi pada masalah menemukan masalah-masalah penting seperti kesempatan pendidikan, energi, atau kriminalitas, informasi yang diperoleh mungkin bersifat makronegatif. Informasi makronegatif menerangkan sebab-sebab dan konsekuensi

${ }^{13}$ Ibid., hlm. 120. 
luas dari kebijakan dan menggunakan datadata agregat untuk menunjukkan mengapa kebijakan-kebijakan dan program-program tertentu tidak berhasil, sebagaimana dibedakan dari informasi mikropositif yang menunjukkan kebijakan dan programprogram apa yang berhasil dan di bawah kondisi spesifik apa.

Ada baiknya pembuat kebijakan tahu bahwa frekuensi kejahatan lebih besar di daerah perkotaan dibanding di daerah pedesaan; tetapi akan lebih berguna lagi untuk tahu bahwa bentuk undang-undang pengendalian penggunaan senjata mengurangi tindak kejahatan yang serius, atau patroli polisi secara intensif merupakan suatu pencegahan terhadap kejahatan.

Bahkan ketika analisis kebijakan yang berorientasi pada aplikasi menghasilkan informasi mikropositif, masih akan terdapat jurang komunikasi yang lebar antara para praktisi analisis kebijakan retrospektif dan prospektif. Dalam suatu instansi tertentu, para analis yang ditugasi mengidentifikasi, membandingkan, dan merekomendasikan alternatif pemecahan masalah mungkin memiliki keterbatasan akses informasi yang dihasilkan oleh praktisi analisis retrospektif.

Demikian juga praktisi analisis prospektif dapat gagal untuk mengkhususkan diri secara cukup rinci jenis informasi yang paling berguna untuk memantau dan mengevaluasi hasil-hasil dari rekomendasi mereka. Akhirnya hasil yang diharapkan dari kebijakan sering dinyatakan secara samar-samar sehingga hampir setiap evaluasinya dapat dianggap tidak relevan karena evaluasi itu tidak menangkap masalah ke arah mana suatu kebijakan tertuju. Masalah-masalah kebijakan sering diformulasikan dengan istilah-istilah yang kabur untuk meraih penerimaan dan menghindari penentangan dari berbagai pelaku kebijakan dan publik pada umumnya.

Pertentangan di antara gaya operasi dari para analis kebijakan menunjukkan bahwa analis yang berorientasi pada disiplin dan masalah kurang berguna dibandingkan dengan analisis yang berorientasi pada aplikasi dan secara keseluruhan analisis retrospektif kurang relevan untuk membuat pemecahan masalah-masalah kebijakan ketimbang analisis prospektif.

Walaupun kesimpulan ini bermanfaat dari sudut pandang para pembuat kebijakan yang harus membuat keputusan-keputusan dan melakukan aksi, kesimpulan tersebut melebih-lebihkan keuntungan dari analisis kebijakan prospektif. Analisis retrospektif, apa pun kelemahannya, memberikan penekanan utamanya pada hasil-hasil aksi dan tidak berisi informasi mengenai tujuantujuan dan sasaran kebijakan, seperti yang terdapat pada analisis prospektif. Lebih dari itu, analisis yang berorientasi pada masalah dan disiplin dapat menawarkan kerangka 
baru untuk memahami proses pembuatan kebijakan, memberi tantangan terhadap perumusan masalah yang konvensional, membalikkan berbagai mitos sosial, dan membentuk opini publik (iklim pendapat) seluruh masyarakat. Analisis retrospektif merupakan yang paling penting di dalam pengaruhnya terhadap prioritas dan pemahaman intelektual, dan tidak begitu efektif dalam menawarkan solusi terhadap masalah-masalah politik yang spesifik.

\section{Analisis Kebijakan yang Terinte-} grasi

Analisis kebijakan yang terintegrasi merupakan bentuk analisis yang mengkombinasikan gaya operasi para praktisi yang menaruh perhatian pada penciptaan dan transformasi informasi sebelum dan sesudah tindakan kebijakan diambil. Analisis kebijakan yang terintegrasi tidak hanya mengharuskan para analis untuk mengaitkan tahap penyelidikan retrospektif dan prospektif, tetapi juga menuntut para analis untuk secara terus-menerus menghasilkan dan mentransformasikan informasi setiap saat. Hal ini berarti bahwa analis dapat terlibat dalam transformasi komponen-komponen informasi-kebijakan searah dengan putaran jarum jam berulang kali sebelum akhirnya pemecahan masalah kebijakan yang memuaskan ditemukan. Analis yang terintegrasi dengan begitu bersifat terus-menerus, berulang-ulang, tanpa ujung, paling tidak dalam prinsipnya. Analisis dapat memulai penciptaan dan transformasi informasi pada setiap titik dari lingkaran analisis, baik sebelum atau sesudah aksi. Selanjutnya, hubungan antara dua tahap analisis kebijakan (misalnya antara perumusan masalah dan peramalan) dapat dipandang sebagai titik dialektis, di mana tidak mungkin untuk menyatakan dengan pasti di mana penggunaan metode analisis kebijakan dimulai dan berakhir. ${ }^{14}$

Analisis yang terintegrasi dapat digambarkan dengan mempertentangkan antara evaluasi-evaluasi retrospektif terhadap kebijakan publik, dan eksperimeneksperimen program kebijakan. Evaluasi retrospektif terhadap kebijakan dan program di dalam sejumlah bidang seperti pendidikan, kesehatan, dan kesejahteraan sosial secara khusus menilai kinerja kebijakan dan program-program yang sedang berjalan.

Sebaliknya eksperimen kebijakan dan program menilai kinerja program dan kebijakan baru dalam hal hasil nyatanya. Untuk menilai bentuk-bentuk baru dari aksi kebijakan di bawah kondisi politik dan administrasi yang realistis, perlu sekali

\footnotetext{
${ }^{14}$ Ibid., hlm. 123.
} 
untuk menciptakan informasi pada setiap tahap analisis kebijakan: perumusan masalah, peramalan, rekomendasi, pemantauan, dan evaluasi. Analisis kebijakan prospektif dan retrospektif, meskipun memulai dan mengakhiri analisis pada waktu yang berbeda, mengharuskan analis melengkapi bagian dari lingkaran analisis.

Analisis kebijakan yang terintegrasi mempunyai semua kelebihan yang dimiliki oleh semua metodologi analisis prospektif dan retrospektif, tetapi tidak satu pun dari kelemahan mereka. Analisis yang terintegrasi melakukan pemantauan dan evaluasi kebijakan secara terus-menerus sepanjang waktu.

Tidak demikian halnya dengan analisis prospektif dan retrospektif, yang menyediakan lebih sedikit informasi. Sebagai contoh, analisis kebijakan prospektif cenderung lemah dalam hal keterbatasannya dan ketidakcukupan informasi yang dihasilkannya menyangkut perubahan nilai tujuan dan sasaran yang terjadi setelah suatu kebijakan diimplementasikan. Sebaliknya, analisis kebijakan retrospektif lemah dalam hal ketidakmampuannya untuk mengarahkan aksi-aksi kebijakan, karena sebagian besar terikat pada informasi yang pasif mengenai konsekuensi kebijakan setelah diimplementasikan.

Akhirnya analisis yang terintegrasi dibangun di atas kekuatan disiplin yang menspesialisasikan pada analisis prospektif (seperti ekonomi, teknik sistem, riset operasi), dan yang menekankan pada analisis retrospektif (seperti ilmu politik, sosiologi, dan hukum). Oleh karena itu, analisis yang terintegrasi adalah multidisiplin di dalam arti yang sebenarnya.

\section{PENUTUP}

\section{Kesimpulan}

Analisis kebijakan ialah suatu rangkaian proses dalam menghasilkan kebijakan. Analisis kebijakan juga bisa diartikan sebagai suatu disiplin ilmu sosial terapan yang menggunakan argumentasi rasional dengan menggunakan fakta-fakta untuk menjelaskan, menilai, dan membuahkan pemikiran dalam rangka upaya memecahkan masalah publik.

Sedangkan dalam suatu analisis kebijakan terdapat lima tipe informasi yang dihasilkan oleh analisis kebijakan adalah: masalah kebijakan, masa depan kebijakan, aksi kebijakan, hasil kebijakan, dan kinerja kebijakan. Kelima tipe informasi tersebut diperoleh melalui lima prosedur analisis kebijakan: perumusan masalah, peramalan, rekomendasi, pemantauan, dan evaluasi.

Selain adanya beberapa informasi yang dihasilkan oleh kebijakan pendidikan yang terpenting ialah adanya beberapa bentukbentuk mengenai analisis kebijakan yakni 
analisis kebijakan prospektif merupakan analisis kebijakan yang berupa produksi dan transformasi informasi sebelum aksi kebijakan dimulai dan diimplementasikan, sebenarnya analisis bentuk ini cenderung menciri cara beroperasinya para ekonom, analis sistem, dan peneliti operasi. Analisis kebijakan retrospektif merupakan analisis sebagai penciptaan dan transformasi informasi sesudah aksi kebijakan dilakukan. Analisis kebijakan yang terintegrasi merupakan bentuk analisis yang mengombinasikan gaya operasi para praktisi yang menaruh perhatian pada penciptaan dan transformasi informasi sebelum dan sesudah tindakan kebijakan diambil.

\section{Daftar Pustaka}

Allison, Graham T., Essence of Decision: Explaining the Cuban Missile Crisis, Boston: Litlle, Brown and Company, 1971.

Coleman, James S., Problem of Conceptualization and Measurement in
Studying Policy Impacts, dalam Public Policy Evaluation, ed. Kenneth M. Dolbeare, Beverly Hill and London: Sage Publications, 1975.

Dunn, William, Pengantar Analisis Kebijakan Publik (Edisi Kedua), terj. Samodra Wibawa, dkk, Yogyakarta: Gadjah Mada University Press, 2003.

Nugroho D., Riant, Kebijakan Publik (Formulasi, Implementasi, dan Evaluasi), Jakarta: Gramedia, 2004.

Quade, E.S., Analysis for Public Decisions, (New York: American Elsevier Publishing Co., 1975.

Ritonga, Rahmansyah, Analisis Kebijakan, http:// sumut. kemenag. go. Id / file / file / Analisis / yxgf 1333599466. pdf.

Suryadi, Ace dan H.A.R. Tilaar, Analisis Kebijakan Pendidikan Suatu Pengantar, Bandung: Remaja Rosdakarya, 1993. 